\title{
3D graphic computation and cost analysis of the underground
}

\section{substation}

\author{
BIAN Li ${ }^{1, a}$ CHEN Dongqing ${ }^{1, b}$ Li Liang $^{1, c}$ and HE Guiyou ${ }^{2, d}$ \\ ${ }^{1}$ Shanghai Electric Power Design Institute Co, Ltd., Shanghai, 200025, China \\ ${ }^{2}$ School of Economics and Management, Tongji University, Shanghai, 200092, China.

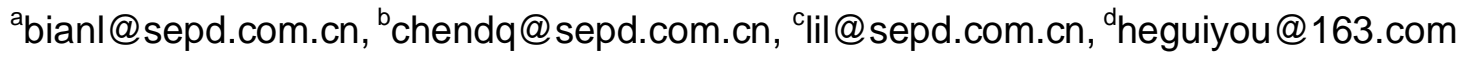

\begin{abstract}
Key Words: underground substation, graphic computation, Building Information Modeling Abstract. Focusing on the underground substation and building information model (Building Information Modeling, BIM) technology, a 3D model framework of underground substation was build. This article teased out the three-dimensional graphic computation process of underground substation, and discussed the significance of cost analysis based the three-dimensional graphic computation.
\end{abstract}

\section{Introduction}

The underground substation was developed rapidly and in shanghai, from the Jin jiang $35 \mathrm{kV}$ substation commissioned in 1987, the Shanghai Stadium substation, People's Square substation, Zi zhong underground substation was built step by step, and especially the 500kV Expo underground built in 2010 is the largest underground substation so far. In addition more underground construction is building, as well as Ji mo substation, Hong yang station.

Because of the complex geological conditions, high water level, the structure of underground substation is complex in shanghai, which is combined with ferroconcrete wall inside and continuous wall outside, the civil works can be divided into the following three parts.

The body portion

The thickness of the inside ferroconcrete wall is $700 \mathrm{~mm}$, waterproof concrete, strength class C35, impermeability class P8. The slab thickness is generally $400-600 \mathrm{~mm}$, the ground design need adapting to the environment, the material of the top floor is modified asphalt and copper composite root barrier-modified, waterproof. Windows and doors on the ground are the same as conventional substation layout, plumbing, HVAC, fire, etc. as needed with underground substation.

The underground continuous wall section

Due to the need for electrical equipment, the depth of $110 \mathrm{kV}$ underground substation is generally over $15 \mathrm{~m}$, more than $23 \mathrm{~m}$ in $220 \mathrm{kV}$. The underground continuous wall as a key foundation pit, the depth nearly reach to $28-35 \mathrm{~m}$, the thickness is $1000 \mathrm{~mm}$. The outer Impermeable curtain use high pressure grouting, and in order to prevent the leakage of the water, the joint portion between the walls using a triangle high pressure jet grouting pile, and Grouting in the toe of wall, not less than $2.5 \mathrm{~m} 3$ concrete each hole.

The pit enclosure and precipitation

The underground substation is different with the conventional substation, such assoil pressure, water pressure, precipitation and seepage pit, anti-floating, etc. The pit enclosure and support is another key point of the building. According to the conventional method of support, the constructor generally use "to support the central pit straight, diagonal corners". Horizontal support beams and 
vertical steel columns combined as a support system. The well-points dewatering are arranged in the inside and outside pit.

\section{Three-dimensional model planning in underground substation civil works}

Building three-dimensional model is the premise to calculation, especially, the overall planning and unified modeling standards is the most important, including the models finesse, model range and specification data description methods. Otherwise the saved time simply defining will be doubly wasted in the late modifications and extensions.

The three-dimensional model object name planning

Parametric feature of architectural models need to ensure finding information accurately and quickly, especially when the three-dimensional model converted to other formats at last. In a visual environment, the component can be quickly identified by name, material, ID number and other parameters. When naming the column, we need clearly identify its cross-sectional size and material, such as $600 * 600 \mathrm{~mm}$ concrete columns, walls are named to clearly identify its thickness and material, such as $240 \mathrm{~mm}$ block wall. Accurately named member also meet the need of cost inspection in graphic computation software.

The three-dimensional model of finesse planning

According to the different stages of the design, the model is updated and deepen gradually. In the preliminary design phase, three-dimensional models are often set up to build the main structure and the support form of the substation. Later on, the steel sampling, interior decoration, detail construction pit support is structured in construction drawing design phase. Ultimately forming a complete building information model. Currently, the depth of modeling in software as shown in Table 2.1. 
Table 2.1 Level of detail for 3D model

\begin{tabular}{|c|c|c|}
\hline Class & Subclass & Level of detail for modeling \\
\hline \multirow[t]{3}{*}{$\begin{array}{l}\text { Building main } \\
\text { body }\end{array}$} & Architectural & $\begin{array}{l}\text { Architectural appearance (Curtain wall, railing, decoration), walls, doors and windows, } \\
\text { lintel, indoor and outdoor staircases, etc. }\end{array}$ \\
\hline & Structure & $\begin{array}{l}\text { Underground foundation, structure beam, beam (L-shaped beams, etc.), column, floor, } \\
\text { underground concrete wall, etc. } \\
\text { The ground structure beam, constructional column, roof board, etc. }\end{array}$ \\
\hline & Decoration & $\begin{array}{l}\text { Floor, walls, wall panels, ceiling, etc. } \\
\text { The earth building roof, metope, etc. } \\
\text { Access port, tuyere, indication lamp, controller, evacuation, etc. }\end{array}$ \\
\hline Slurry wall & Structure & $\begin{array}{l}\text { Underground continuous wall } \\
\text { Scope of high pressure jet grouting pile grouting }\end{array}$ \\
\hline $\begin{array}{l}\text { Foundation pit } \\
\text { support }\end{array}$ & Structure & $\begin{array}{l}\text { Reinforced concrete rectangular beam support, oblique support } \\
\text { Steel pipe support to pass the structure column } \\
\text { Bored piles etc. }\end{array}$ \\
\hline \multirow[t]{3}{*}{ HVAC } & Air system & $\begin{array}{l}\text { Duct including diffuser, air supply and return air tuyere, VAV box, etc. } \\
\text { Air conditioning and ventilation equipment, including air handling units, fan coil units, } \\
\text { air conditioner, etc. } \\
\text { Including fire valve, control valve regulating valve, balance valve, etc. }\end{array}$ \\
\hline & Water system & $\begin{array}{l}\text { Pipe of diameter more than } 50 \mathrm{~mm} \text {, air conditioning heat and cold source room } \\
\text { equipment }\end{array}$ \\
\hline & $\begin{array}{l}\text { Power } \\
\text { system }\end{array}$ & Pipe of diameter more than $50 \mathrm{~mm}$ \\
\hline \multirow[t]{2}{*}{$\begin{array}{l}\text { Water supply and } \\
\text { drainage }\end{array}$} & $\begin{array}{l}\text { Water supply } \\
\text { and drainage }\end{array}$ & $\begin{array}{l}\text { Pipe of diameter more than } 50 \mathrm{~mm} \\
\text { Water supply and drainage equipment, including various types of pumps, boilers, hot } \\
\text { and cold water unit, tank, etc. } \\
\text { Sanitary equipment, including toilet lavabo, sitting and standing type, etc. }\end{array}$ \\
\hline & Fire sprinkler & $\begin{array}{l}\text { Pipe of diameter more than } 50 \mathrm{~mm} \\
\text { Fire equipment, such as water injection under injection, etc. }\end{array}$ \\
\hline \multirow[t]{3}{*}{ Electric } & $\begin{array}{l}\text { Power } \\
\text { system }\end{array}$ & $\begin{array}{l}\text { Main cable tray and trough; Contains the main electrical equipment transformer, } \\
\text { switchgear, power distribution box, socket box, etc. }\end{array}$ \\
\hline & $\begin{array}{l}\text { Lighting } \\
\text { system }\end{array}$ & $\begin{array}{l}\text { Lighting equipment, electrical equipment } \\
\text { Do not model switch and socket }\end{array}$ \\
\hline & $\begin{array}{l}\text { Weak current } \\
\text { system }\end{array}$ & Main elv engine equipment, main system and the main feeder trough \\
\hline
\end{tabular}

BIM model is the basis of technical implementation, previous rulemaking is a crucial step, which will impact on subsequent participants and deepen work directly. Different professional models can be invoked and realized information collaborative in a unified system by detailed name planning in underground substation civil works.

\section{Three-dimensional graphic computation process in underground substation civil works}

Construction of three-dimensional model provides convenience for graphical computation, a standardized process is very necessary in order to reduce the information transfer distortions and omissions between the different participants. 
Firstly, the axis positioning is the most important, integrated architectural, structural, MEP model requires a unified grid reference location, otherwise, the model will not integrate. Accurate grid can ensure the component identification accuracy when importing CAD drawings in software.

Secondly, the component attributes directly related to the accuracy drawing in the three-dimensional model, the component attribute determines the height, size, thickness, elevation member, etc. However, when the component attribute is the default state, the property will automatically change according to certain public data. Such as the height of the column, when it is the default property, it will go along with the floor height. After defining the component properties, software can realize outputting the complete list after editing component practices, by "Basket item" and "Query fixed term" finding the appropriate inventory.

Finally, except for the architecture and installation module in the software, the steel sampling make the steel computation easier. In addition, the software provides parameterized cells (such as foundation, structure beams), we can draw a polygon shaped member by the editor, but we cannot draw member without capturing precise endpoint because of the fixed computing modeling process rules, so that the entire modeling process is more sophisticated, according with actual construction method.

\section{The significance of cost analysis based on the three-dimensional graphic computation}

As a transformative tool, the three-dimensional graphic computation will have a profound impact on costing process, will effectively improve the reliability of the cost calculations. American Hillwood project cost engineers saves 92 percent of the time by using a three-dimensional calculation method. Especially in the power construction industry, the "Over estimate, Over budget" phenomenon still exists, reliable data is essential to reduce this phenomenon. In summary, the three-dimensional graphic computation based BIM can achieve greater economic efficiency.

At first, the cost engineer are divorced from the tedious work by the three-dimensional graphic computation, they can have more time and effort for valuable work, such as price information gathering, risk assessment, applying quotas and other research, forming a more accurate consulting report.

Secondly, the three-dimensional graphic computation is more accurate than the traditional method. Because of the large amount reinforced concrete in the underground substation, computing process is very complicated, the three-dimensional graphic computation will make the calculation work getting rid of human factors, reaching more scientific data.

Finally, three-dimensional graphic computation is more efficient than the traditional method. In the underground substation, economic analysis and comparison of different programs is necessary due to the large investment, the cost variation caused by the design change will timely feedback to the design based the three-dimensional graphic, easy to control cost in the design phase.

\section{Conclusion}

Saving construction land will be the key point in large urban areas, although high land prices the electricity load is higher, the underground substation construction plays an important role in the development of the city. The civil cost is constraint to the developing of underground substation. On the one hand, the design need to optimize by combining underground substation and civil construction, using miniaturized devices, reducing floor space and story, reducing the concrete of pit enclosure and support; on the other hand, the introduction of innovative construction techniques--BIM in the field of cost controlling is necessary, each consult need more study on the three-dimensional graphic computation, improving work efficiency and calculation accuracy, ultimately promoting the entire construction industry sustainable development. 


\section{References}

[1] Eastman C, Teicholz P, Sacks R, Liston K. BIM handbook: A guide to building information modeling for owners, managers, designers, engineers, and contractors (2nd Edition) [M]. New Jersey: John Wiley \& Sons, Inc., 2011.

[2]Linfang Cao. The plan and design of the underground substation [J].Shanghai Electric Power, 2002, 02:8-11

[3] Yu Zou. Research on the Relationship between Deep Foundation Pit Design of $220 \mathrm{kV}$ Underground Substation and Peripheral Environmental Protection [J]. East China electric power, 2011, 08:1332-1334

[4]building SMART BIM Project Execution Planning Guide.2010.7

[5]CIFE. (November 22, 2007). CIFE Technical Reports [WWW document] URL http://cife.stanford.edu/Publications/index.html

[6]United States National Building Information Modeling Standard. National Institute of Building Sciences. Version 1-Part 1[R].

[7]Autodesk, 2002. Autodesk white paper for BIM. http://usa.autodesk.com /2008/4 